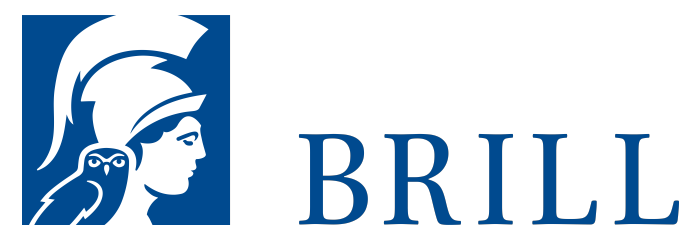

\title{
Die Namenlosen zwischen Licht und Schatten
}

\section{Das Auge der Geschichte IV}

Author: Georges Didi-Huberman

Wie wird das einfache Volk dargestellt? Dieser ebenso sehr politischen wie ästhetischen Frage widmet sich Georges DidiHuberman ausgehend von Forderungen, die man bei Walter Benjamin findet (die Geschichte muss den Namenlosen eine Stimme geben) oder bei Hannah Arendt (in jeder Politik muss ein Stück Menschlichkeit zu finden sein).

Zurückgegriffen wird dabei auf Dichter (Villon, Hugo, Baudelaire), Maler (Rembrandt, Goya, Courbet) und Photographen (Walker Evans, August Sander, Philippe Bazin), die den »kleinen Leuten« ihre Aufmerksamkeit geschenkt haben. Das Kino kennt diese »kleinen Leute « als Statisten, die den Hintergrund für den Auftritt der Stars abgeben. Sie bilden ein wichtiges historisch-politisches Motiv des Kinos - von seinen Anfängen (Arbeiter verlassen die Lumière-Werke) bis hin zu Eisenstein, Rossellini und darüber hinaus. Sehr ausführlich analysiert wird hier das Schaffen von Pier Paolo Pasolini, seine Art, die »verlorenen einfachen Menschen« in ihren »überlebenden Gesten« wiederzufinden.

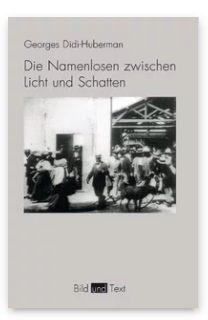

Pages: 295

Seiten, $59 \mathrm{~s} / \mathrm{w}$

Abb.

Language:

German

Subjects: Art

History, Art

History

Publisher: Brill |

Fink

Series:

Bild und Text

Paperback

Publication date:

29 Sep 2017

ISBN: $978-3^{-}$

7705-6010-3

List price

USD $\$ 80.00$ 
Georges Didi-Huberman ist Kunsthistoriker und Philosoph und lehrt an der „École des Hautes Études en Sciences Sociales“, Paris.

For more information see brill.com

Order information: Order online at brill.com +44 330 333 0049 | customerservices@brill.com Submission information: brill.com/authors

Titles published by Brill | Fink, Brill | mentis or Brill | Schöningh: +49(o)71 5413279216 | brill@brocom.de 